\title{
Preliminary results of XRF and XRD analyzes for lithofacial characteristics of the Doirentsi Formation reservoir carbonates in the south-central part of the Moesian Platform
}

\section{Първоначални резултати от XRF и XRD анализи за литофациална характеристика на резервоарните карбонати на Дойренската свита в южната централна част на Мизийската платформа}

\author{
Eva Marinovska, Nikola Botoucharov \\ Ева Мариновска, Никола Ботушаров
}

Sofia University "St. Kliment Ohridski", Department of Mineralogy, Petrology and Economic Geology, 1504 Sofia;

E-mails: evarmarinovska@gmail.com; botnd@gea.uni-sofia.bg

\begin{abstract}
The main objective of the study is to determine the lithofacial characteristics of the Doirentsi Formation reservoir carbonates in the range of the south-central part of the Moesian platform by XRD and XRF analyzes. The obtained results demonstrate the chemical and phase composition and supplement the field description of the Middle Triassic limestones and dolomites. This will allow the creation of realistic 3-D reservoir models for gas condensate fields Pisarovo and Devetaki in the future.
\end{abstract}

Keywords: Moesian Platform, XRD, XRF, lithofacies, Doirentsi Formation.

\section{Въведение}

Карбонатните скали имат съществен принос в търсещо-проучвателния процес за нефт и газ, изпълнявайки функциите основно на природни резервоари, представляващи около половината от известните находища в света. Изучаването на среднотриаските карбонатни комплекси в Централна Северна България и тяхната литофациална характеристика са от изключително значение за изясняването на колекторските им параметри с цел избор на подходящи експлоатационни методи, максимално извличане на запасите от тях, както и очертаването на бъдещи перспективни зони за сондиране. Литофациалната характеристика на карбонатните скали е свързана основно с техния минерален и гранулометричен състав, текстурни и структурни особености. Първоначалните резултати се получават от полевото изучаване на скалите, микроскопското наблюдение на дюншлифи, химичните анализи и катодната луминесцен- ция. В допълнение на тези изследвания рентгено-дифрактометричният анализ (XRD) и рентгено-флуоресцентният анализ (XRF) детайлизират химическия и фазов състав и допълват полевото описание на седиментите.

Целта на настоящото изследване е ясно да се определи литофациалната характеристика на резервоарните карбонати на Дойренската свита в обхвата на южната централна част на Мизийската платформа чрез XRD и XRF анализи. Получените първоначални данни от сондажната ядка дават насоки за литоложките особености и диагенетичните промени, оказващи влияние в една или друга степен върху резервоарните свойства на карбонатните скали в Писаровското и Деветашкото газокондензатно находище. Получените резултати от химическите анализи не само ще детайлизират полевите литоложки описания, но ще могат да се съпоставят с други лабораторни изследвания с цел задълбоченото изучаване на колекторските качества на Дойренската свита в изследвания район. 


\section{Тектонска позиция и търсещо- проучвателни работи в изследвания район}

Районът на изследване, включващ двете газокондензатни находища Писарово и Деветаки, е локализиран в южната централна част на Мизийската платформа (фиг. 1). Там в най-южната зона на Янтренско-Искърската моноклинала е разположено Борованско-Тученишкото грабеновидно понижение, където се намира газокондензатното находище Писарово. Писаровската приразломна структура представлява част от едноименен хорст, непосредствено на юг от Дъбнишко-Гривишко-Одърнишката издигната зона. Деветашката площ от своя страна е в пределите на Ловешко-Търновската моноклинала, обхващаща част от Южномизийското периплатформено понижение или област (Bokov et al., 1987), наричано още Южен платформен склон (Zagorchev et al., 2009).

Първите детайлни данни за литолого-стратиграфската характеристика в Писаровската и Деветашката площи се получават в резултат от необходимостта да се изясни дълбочинния геоложки строеж и нефтогазоносна перспективност на Централна Северна България (Kalinko et al., 1976; Atanasov, Bokov, 1983).

Предприемат се голям обем геофизични проучвания през 1947-1950 г. с провеждането на гравиметрични и магнитометрични изследвания. През 1959 г. са набелязани няколко локални структури в пределите на т.нар. Плевенски гравитационен максимум. На тази основа започват системни геоложки проучвания за търсене на нефтени и газови находища, в резултат на което в периода 1962-1982 г. са открити Долнодъбнишкото, Горнодъбнишкото нефтено находище и Писаровското газокондензатно находище, привързани към среднотриаска седименти (Дойренска свита). Междувременно през 1963 г. са проведени първите сеизмични проучвания в района на селата Умаревци, Горан, Дойренци и Деветаки. През 1966-1967 г. успоредно с проучванията в района на с. Умаревци са проведени полудетайлни сеизмични работи в района на с. Деветаки и е заложен търсещо-проучвателния сондаж Р-2 в свода на едноименната структура. Чрез него през 1969 г. във варовици с триаска възраст е открито газокондензатното находище Деветаки.

\section{Резултати и дискусия}

Настоящото изследване включва XRD и XRF анализи на скали от Дойренската свита, реализирани в Химическа лаборатория за анализ на геоложки материали и лаборатория по Рентгеноструктурен анализ към ГГФ на Софийския университет „Св. Климент Охридски“, представени в таблица 1.

Химичният състав е определен чрез XRF, a праховата рентгенова дифракция показва, че основните фази са карбонати - калцити и доломити. Съдържанието на калцит във варовиците варира от 95,6 до $100 \%$, а количеството на доломит в тях достига 4,2\%. В доломитите се установява съдържание на калцит от 1,2 до $7,8 \%$. Данните от химичния анализ показват, че в скалите присьстват още $\mathrm{Mn}, \mathrm{Fe}, \mathrm{Al}, \mathrm{Si}$. Желязо-

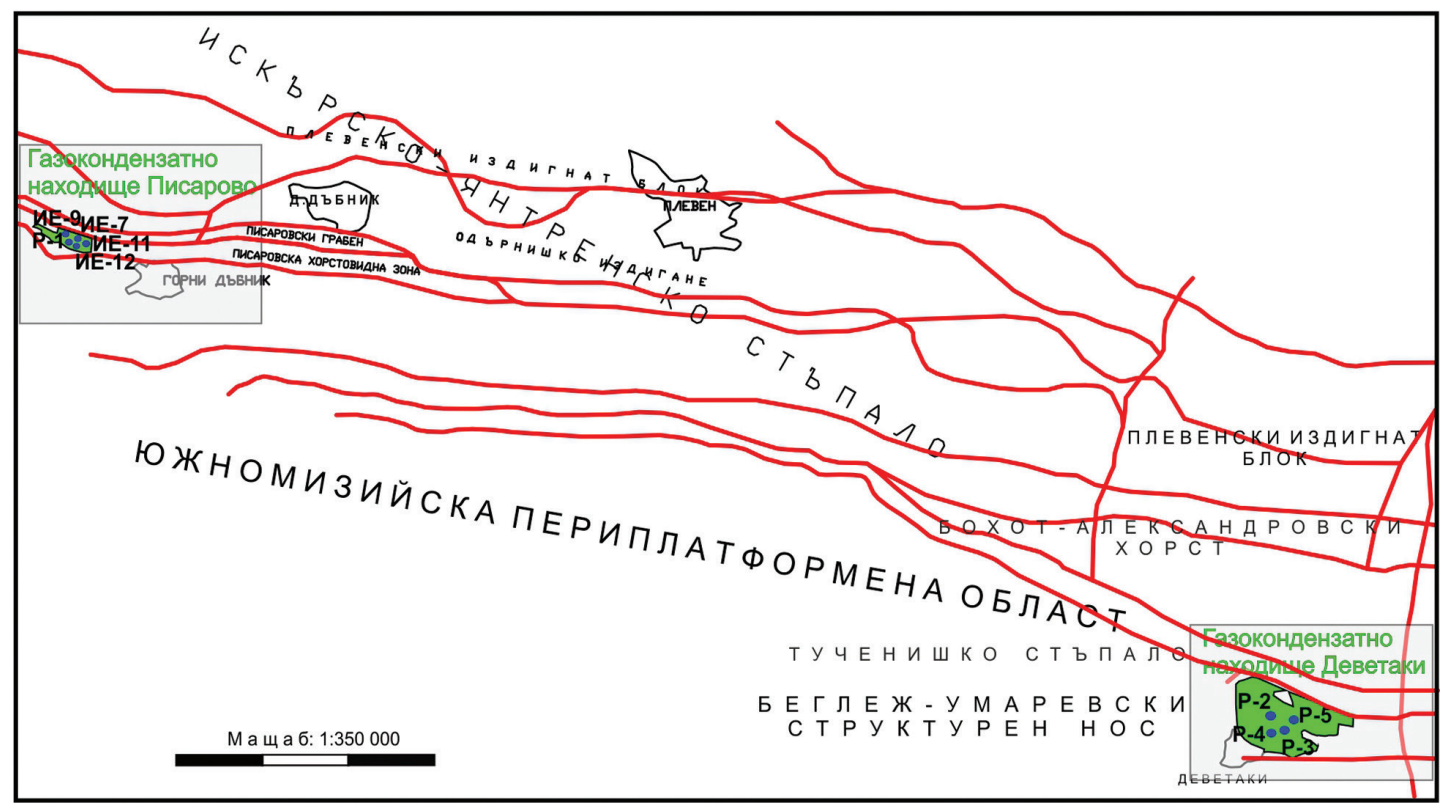

Фиг. 1. Тектонска схема на изследвания района в обхвата на Мизийската платформа, съставена по данни от картата на изучеността на територията на Централна Северна България в М 1:200 000 (Atanasov, Bokov, 1983; Atanasov et al., 1984) с допълнения 
Таблича 1. Химически и фазов състав на карбонатни скали от газокондензатни находища Писарово (P-1 до ИЕ-12) и Деветаки (P-2 до Р-5)

\begin{tabular}{|c|c|c|c|c|c|c|c|c|c|}
\hline Сондаж № & P-1 & ИЕ-7 & ИЕ-9 & ИЕ-11 & ИЕ-12 & P-2 & P-3 & P-4 & P-5 \\
\hline $\mathrm{SiO}_{2}$ & 0,94 & 0,84 & 1,31 & 0,75 & 0,57 & 0,66 & 3,66 & 0,85 & 2,71 \\
\hline $\mathrm{TiO}_{2}$ & 0,02 & 0,02 & 0,02 & 0,02 & 0,00 & 0,01 & 0,04 & 0,01 & 0,04 \\
\hline $\mathrm{Al}_{2} \mathrm{O}_{3}$ & 0,42 & 0,26 & 0,54 & 0,25 & 0,14 & 0,17 & 0,90 & 0,31 & 0,74 \\
\hline $\mathrm{Fe}_{2} \mathrm{O}_{3}$ & 0,36 & 0,08 & 0,34 & 0,35 & 0,11 & 0,13 & 0,46 & 0,10 & 0,34 \\
\hline $\mathrm{MnO}$ & 0,01 & 0,00 & 0,01 & 0,01 & 0,01 & 0,00 & 0,01 & 0,00 & 0,01 \\
\hline $\mathrm{MgO}$ & 21,65 & 1,36 & 21,45 & 22,42 & 0,25 & 0,13 & 0,50 & 0,26 & 0,59 \\
\hline $\mathrm{CaO}$ & 30,68 & 53,95 & 30,30 & 29,57 & 55,43 & 55,28 & 52,21 & 54,98 & 52,90 \\
\hline $\mathrm{Na}_{2} \mathrm{O}$ & 0,06 & 0,01 & 0,10 & 0,06 & 0,00 & 0,00 & 0,02 & 0,01 & 0,02 \\
\hline $\mathrm{K}_{2} \mathrm{O}$ & 0,05 & 0,01 & 0,07 & 0,01 & 0,00 & 0,00 & 0,12 & 0,02 & 0,09 \\
\hline $\mathrm{P}_{2} \mathrm{O}_{5}$ & 0,05 & 0,01 & 0,05 & 0,05 & 0,01 & 0,01 & 0,10 & 0,03 & 0,09 \\
\hline LOI* & 45,76 & 43,36 & 45,82 & 46,51 & 43,49 & 43,55 & 41,96 & 43,39 & 42,43 \\
\hline Total & 100,00 & 99,91 & 100,00 & 99,99 & 100,00 & 99,94 & 99,97 & 99,96 & 99,96 \\
\hline $\mathrm{Sr}$ & & 0,091 & & 0,008 & & 0,061 & 0,027 & 0,038 & 0,044 \\
\hline \multicolumn{10}{|c|}{ Фазов състав (\%) (от 100\% кристална фаза) } \\
\hline доломит & 92,2 & 4,2 & 98,8 & 98,8 & - & - & - & - & - \\
\hline калцит & 7,8 & 95,6 & 1,2 & 1,2 & 100 & 100 & 97,8 & 100 & 100 \\
\hline кварц & - & - & - & - & - & - & 2,2 & - & 2,7 \\
\hline $\begin{array}{c}\text { Литоложка } \\
\text { характеристика }\end{array}$ & доломит & варовик & доломит & доломит & варовик & варовик & варовик & варовик & варовик \\
\hline Дълбочина (m) & 3722 & 3718 & 3729,25 & 3732,30 & 3722 & 3817,75 & 3965,90 & 3968,70 & 3821 \\
\hline
\end{tabular}

*LOI - загуби при накаляване $\left(1000^{\circ} \mathrm{C}\right)$

то и манганът са обичайни изоморфни примеси както в калцитовия, така и в доломитовия тип структура ( $\mathrm{Ca}, \mathrm{Mg}, \mathrm{Fe} \mathrm{Mn}) \mathrm{CO}_{3}$. В химичния състав количеството на $\mathrm{Fe}_{2} \mathrm{O}_{3}$ е определено в границите $0,08-0,46$ wt\%. Присьствието на Al и Si във всички проби показва наличие на алумосиликатна фаза, в количество под границата на откриване на праховия дифракционен метод и не може да бъде определена.

Изследваните образци от сондажи Р-9, ИЕ-11, P-1 Писарово съдържат 92-99\% доломит и калцит до $\sim 8 \%$, като $\mathrm{Fe}$ и $\mathrm{Mn}$ изоморфно заместват калция и магнезия. Химичният анализ показва алумосиликатна фаза под $1 \%$, или под границата на откриване с прахова рентгенова дифракция.

В сондажи P-3, P-4 и P-5 Деветаки образците съдържат 98-100\% калцит и до около 3\% кварц, а количеството на $\mathrm{MgO}$ показва вариации от 0,26 до $0,6 \mathrm{wt} \%$, като отново са установени $\mathrm{Fe}$ и $\mathrm{Mn}$, които най-вероятно изоморфно заместват калция.

Образецът от сондаж ИЕ-7 Писарово може да бъде определен като доломит-съдържащ варовик, поради относително високото съдържание на доломит - 4,2\%. Спрямо съществуващите класификации за карбонатните скали не може да бъде дефиниран като доломитизиран варовик, тъй като пределната стойност за съдържание на доломитов компонент е над 10\%.

Получените резултати от XRD и XRF анализите ще допринесат за цялостната литофациал- на характеристика на резервоарните карбонати на Дойренската свита и допълване на полевите наблюдения върху ядка и шлам. Очертаването на пространствените литофациални взаимоотношения по сондажни данни ще позволи да се дефинират перспективните колекторски интервали с оглед създаването на реалистични 3D резервоарни модели за газокондензатните находища Писарово и Деветаки. Приоритет на тези 3D модели е определяне на зоните с остатъчни запаси от газ и кондензат и тяхната бъдеща експлоатация чрез наклонено-насочени или хоризонтални сондажи.

\section{Литература \\ References}

Atanasov, A., P. Bokov (Eds.). 1983. Geology and Oil and Gas Perspectives of the Moesian Platform in Central North Bulgaria. Sofia, Tehnika, 288 p. (in Bulgarian).

Atanasov, A., P. Bokov, G. Georgiev, I. Monahov. 1984. Major features in the geological structure of North Bulgaria in connection with the oil and gas perspectives. - Works NIPI, 1, 29-41 (in Bulgarian).

Bokov, P., G. Georgiev, I. Monahov, An. Atanasov, S. Jelev, Ch. Dachev, D. Jordanov, M. Vavilova, M. Nikolov, R. Ognianov. 1987. Tectonic zoning. - In: Bokov, P., Ch. Chemberski (Eds.). Geological Prerequisites for the Oil and Gas Potential of Northeastern Bulgaria. Sofia, Tehnika, 109-119 (in Bulgarian).

Kalinko, M. K. (Ed.). 1976. Geology and Oil and Gas in the North Bulgaria. Moscow, Nedra, 243 p. (in Russian).

Zagorchev, I., Ch. Dabovski, T. Nikolov (Eds.). 2009. Geology of Bulgaria. Vol. II. Part 5. Mesozoic Geology. Sofia, Prof. Marin Drinov Academic Publishing House, 766 p. (in Bulgarian with English abstract). 